\title{
REVIEW
}

\section{Behçet's disease: infectious aetiology, new autoantigens, and HLA-B51}

\author{
H Direskeneli
}

Behçet's disease (BD) is a multisystemic disorder with mucocutaneous, ocular, arthritic, vascular, and central nervous system involvements. ${ }^{1}$ Recent developments in the immunopathogenesis of $\mathrm{BD}$ are discussed in this review. Box 1 summarises the major aspects covered.

\section{Neutrophil activation}

Neutrophils are mature immune cells with a very short life in vitro and have a pivotal role in innate immune responses. As typical BD lesions such as pustular folliculitis, pathergy reactions, and hypopyon have significant neutrophil infiltrations, neutrophil functions and activation status have been extensively investigated. ${ }^{12}$ Conflicting reports of increased, normal, or decreased basal and fMLP stimulated superoxide productions, phagocytosis, chemotaxis, and neutrophil-endothelial adhesion in BD may reflect the status of clinical activity, in vivo neutrophil activation, drug effects, or just methodological problems of investigating neutrophils. ${ }^{3-9}$ In a recent study, which showed decreased fMLP stimulated superoxide production in BD and patients with sepsis, consecutive restimulations of prestimulated BD neutrophils produced a smaller increase in superoxide production than in healthy controls, implying a state of in vivo neutrophil preactivation. 9 An in vivo "primed" state of neutrophils with a dual signalling system for activating neutrophil oxidase has been suggested previously. ${ }^{10}$ Agents such as fMLP or the cytokines, tumour necrosis factor $\alpha(\mathrm{TNF} \alpha)$ and granulocyte monocyte colony stimulating factor, have been shown to increase tyrosine phosphorylation of various intracellular proteins and to prime neutrophils in vivo without full activation, which might also be the case in $\mathrm{BD}$ with its proinflammatory cytokines. In HLAB51 transgenic mice, a presumed model for BD, the only abnormality seen is increased superoxide release in response to fMLP. ${ }^{6}$ High superoxide responses were also present in HLA-B51+ patients and healthy controls in the same study, ${ }^{6}$ but this has not been confirmed. ${ }^{9}$

\section{Cellular and humoral immunity}

$\mathrm{T}$ cell activation, both in the peripheral blood and tissue specimens, is present in BD. A possibly antigen driven change in the peripheral blood CD4+ and CD8+ T cell repertoire, with oligoclonal $\mathrm{T}$ cell receptor $\mathrm{V} \beta$ subset increases,
Box 1 Immunopathogenic aspects of Behçet's disease

- Neutrophil activation

- Cellular and humoral immunity

- Antigenic stimuli

- Herpes simplex virus

- Streptococci and superantigens

- Heat shock proteins (65 kDa, $\alpha \beta$ crystallin)

- HLA-B51 and antigen presentation

- Retinal-S antigen and HLA-B51 as autoantigens

- Vascular disease and antiendothelial cell antibodies

- Sex aspects

has been observed. ${ }^{11}$ However, the high individual variability of dominant $\mathrm{V} \beta$ subsets between patients make it impossible to implicate a single antigen as driving the $\mathrm{T}$ cell activation. $\gamma \delta+\mathrm{T}$ cells are also increased, both in the peripheral blood and tissue infiltrations, with high expressions of the early $\mathrm{T}$ cell activation markers CD29 and CD69. ${ }^{12} 13$

As for most other autoimmune disorders and vasculitides, the Th1-type cytokine profile is predominant in BD. Both CD4+ and CD8+ T cells, which produce the Th1 type proinflammatory cytokines interleukin 2 (IL2) and interferon $\gamma$ (IFN $\gamma$ ), are increased in the peripheral blood, ${ }^{14}$ and correlate with disease activity. ${ }^{15}$ IL12, which drives the Th1 response in naive $T$ cells, is raised in BD sera, in correlation with Th1 lymphocytes. Th2 lymphocytes and levels of Th2 cytokines are generally found to be low, ${ }^{15} 16$ except in a study in which there were high in vitro IL4, IL10, and IL13 levels. ${ }^{17}$ Peripheral $\gamma \delta+\mathrm{T}$ cells also secrete IFN $\gamma$ and $\mathrm{TNF} \alpha$ as major cytokines, which it is suggested are of the Th1 type. ${ }^{13}$

Although BD does not have the features of a classical autoimmune disorder, such as female dominance, hypergammaglobulinaemia, Sjögren's syndrome, and antinuclear antibodies, ${ }^{18}$ some B cell activity, such as increased spontaneous immunglobulin secretion, is reported. ${ }^{19}$ Autoantibodies such as antiendothelial cell (AECA), antilymphocyte, and anticardiolipin antibodies, especially of IgA isotype, are also present. ${ }^{20-22}$ Although the total $\mathrm{B}$ cell number is 
normal, they express increased levels of activation markers such as CD13, CD33, CD80, and the memory marker CD45RO. ${ }^{23}$ The low level of $\mathrm{CD} 5+\mathrm{CD} 19+\mathrm{B}$ cells which produce autoantibodies suggests that BD is distinct from classical autoantibody mediated disorders. However, as the current role of B cells in the immune system is not limited to antibody production, but also includes antigen presentation, the activated and memory type B cell profile might modulate $\mathrm{T}$ cell activation in $\mathrm{BD}$.

\section{Antigenic stimuli}

HERPES SIMPLEX VIRUS

A viral cause for $\mathrm{BD}$ was first postulated by Behçet in $1937^{24}$ and, later, viral particles were claimed to be isolated from patients' fluids. ${ }^{25}$ Although herpetiform ulcers are not common, herpes simplex virus (HSV) is currently the only virus possibly associated with $\mathrm{BD} .{ }^{12}$ Serum anti-HSV-1 antibodies are found in a higher proportion of patients with $\mathrm{BD}$ than in controls, and circulating immune complexes with the HSV-1 antigen have been reported. ${ }^{26}$ HSV DNA has been demonstrated in the genital and intestinal ulcers of patients with $\mathrm{BD},{ }^{27}$ but not in oral ulcers. ${ }^{26}$ Thirty per cent of ICR mice inoculated with HSV are reported to have Behçet's disease-like symptoms, with genital ulcers, skin, and eye lesions, ${ }^{28}$ which attenuate with Th2-type cytokine expression. ${ }^{29}$ However, a high mortality and some different mucocutaneous lesions are also present in this model. Anti-HSV immunity is also common in normal subjects, and data on the therapeutic effects of antiviral treatment in $\mathrm{BD}$ are scarce and the results controversial. ${ }^{12}$

\section{STREPTOCOCCI AND SUPERANTIGENS}

As BD starts mostly from the oral mucosal surface (oral aphthae are the first manifestation in $70 \%$ of patients), oral microbial flora have long been implicated in the pathogenesis. Clinical observations such as increased oral manifestations after dental treatment, hypersensitivity to streptococcal skin tests, dominance of atypical streptococcal species in patients with the oral flora of $\mathrm{BD}$, and recent reports of beneficial antibacterial treatment suggest a role for streptococci in $\mathrm{BD} .^{26} 3031$

KTH-1 (a crude extract of Streptococcus sanguis SSH-83) causes increased IL6 and IFN $\gamma$ secretion by peripheral blood $\mathrm{T}$ cells of patients with BD. ${ }^{32} \mathrm{KTH}-1$ also up regulates $\gamma \delta \mathrm{T}$ cells in short term $\mathrm{T}$ cell cultures, and $\mathrm{KTH}-1$ specific $\gamma \delta \mathrm{T}$ cell lines secrete the proinflammatory mediators IL6, IL8, and TNF $\alpha .{ }^{33}$ In addition to streptococcal antigens, Escherichia coli and Staphylococcus aureus also activate BD lymphocytes to release increased amounts of IFN $\gamma$ and IL6. T lymphocytes in BD secrete IFN $\gamma$ in response to lower doses $(1-10 \mathrm{pg} / \mathrm{ml})$ of the staphylococcal superantigens SEB and SEC1 than controls, and Hirohata and Hashimoto proposed a $\mathrm{T}$ cell hyperreactivity in $\mathrm{BD} .^{34}$

60/65 kDa HEAT SHOCK PROTEIN (HSP)

Heat shock proteins, especially $60 / 65 \mathrm{kDa}$ HSP (HSP65), are possible candidate antigens for
BD. HSPs have scavenger roles for other intracellular proteins under denaturating stress conditions such as infections, hypoxia, trauma, and toxic drugs. Various immune mechanisms are described for the role of HSPs in infectious, autoimmune, and malign disorders. ${ }^{35}$ As significant sequence homology exists between the mammalian and microbial HSPs (mycobacterial and human HSPs60/65 have over 50\% homology), it has been suggested that bacterial HSP responsive $T$ cells stimulate autoreactive $\mathrm{T}$ cells by cross reactivity mechanisms. ${ }^{26}$

HSP65 is expressed abundantly in epidermal regions of active skin lesions, such as erythema nodosum and mucocutaneous ulcers in $\mathrm{BD} .^{36}$ Lehner et al first suggested the concept of HSP65 as a pathogenic antigen in BD by identifying anti-HSP65 antibodies cross reactive with oral mucosal homogenates and oral streptococci. ${ }^{37}$ Four epitopes of mycobacterial HSP65 (amino acid sequences 111-25, 154$72,219-33$, and 311-26) were recognised to be immunodominant for $\mathrm{T}$ and $\mathrm{B}$ cell responses. ${ }^{38}{ }^{39} \mathrm{~T}$ cell responses to these mycobacterial HSP65 derived peptides and to their $50-80 \%$ homologues on human HSP60 were significantly higher in patients with $\mathrm{BD}$ from UK, Japan, and Turkey than in controls. ${ }^{40-42}$ HSP peptide responsive T cells were mainly of the $\gamma \delta \mathrm{T}$ cell subset in the $\mathrm{UK},{ }^{40}$ whereas CD $4+\mathrm{T}$ cells were dominant in Turkey and Japan. ${ }^{41}{ }^{43}$ However, $\gamma \delta \mathrm{T}$ cells were also present in tissue specimens where HSP65 expression was up regulated, suggesting that the local HSP responsive $\mathrm{T}$ cell repertoire might be different from that of peripheral blood. ${ }^{36}$

Purified protein derivative and HSP65specific long term $\mathrm{T}$ cell lines (mainly TCR $\alpha \beta+\mathrm{CD} 4+$ or $\mathrm{CD} 8+$ ) are also highly reactive to human HSP60 derived peptides in both patients with $\mathrm{BD}$ and healthy controls. ${ }^{44}$ Most purified protein derivative stimulated lines responded to epitope $425-41$ of HSP60 in patients with BD (an epitope not described in primary cultures of patients with $\mathrm{BD}$ ), whereas epitope 336-51 dominated in controls, suggesting that the patterns of response and the immunodominance of epitopes may differ in patients with $\mathrm{BD}$ from those of healthy controls.

When anti-HSP responses were compared with antibacterial responses ( $S$ sanguis and $E$ coli) to investigate cross reactivity further, $\mathrm{CD} 4+\mathrm{T}$ cell responses were mainly seen against HSP60 peptides, whereas CD11b+, CD4+CD56+ cytotoxic $\mathrm{T}$ cell responses were dominant against whole bacterial extracts. ${ }^{43}$ The increased presence of similar cytotoxicsuppressor CD4+CD16+ and CD4+CD56+ $\mathrm{T}$ cell subsets in the unstimulated peripheral blood $\mathrm{T}$ cell repertoire of patients with $\mathrm{BD}$ also implicates an in vivo bacterial prestimulation. ${ }^{45}$

Similarly to the T cell studies, "cross reactivity" is also demonstrated for anti-HSP60 antibodies. Both antistreptococcal and antiretinal HSP60 antibodies are raised in the serum samples of patients with $\mathrm{BD}$ and uveitis, with significant cross inhibition. ${ }^{46}$ Increased antiHSP65 antibody responses are also present in 
the cerebrospinal fluid (CSF) of patients with neuro-BD with parenchymal involvement. ${ }^{47}$

In an animal model of HSP subcutaneous inoculation in rats, human HSP derived, immunodominant peptides caused an experimental uveitis without other symptoms of BD. ${ }^{48}$ Oral administration of peptides also induced uveitis, causing an "oral triggering", in contrast with most models of "oral tolerance", where the mucosal immune encounter with pathogenic antigens suppresses immune activity. ${ }^{49}$ Heat shock to oral mucosa also increases $S$ sanguis colonisation and ocular inflammation in mice, suggesting that stress may be crucial for the breakdown of mucosal defences and anti-HSP reactivity. ${ }^{50}$

In some other experimental models, such as adjuvant arthritis, $\mathrm{T}$ cell responses to self HSP60 are protective. $^{51}$ As the antiinflammatory cytokines, IL4 and transforming growth factor $\beta$ are released after in vitro human HSP60 stimulation, self HSP reactivity is also claimed to be immunosuppressive in juvenile and adult rheumatoid arthritis. ${ }^{52}$ However, stimulation with the human HSP60 peptide 336-51 produced IFN $\gamma, \mathrm{TNF} \alpha$, and IL12 in BD lymphocytes, whereas the Th2 cytokines IL4 and IL10 suppressed the proliferative responses. $^{53}$ On the other hand, the only HSP6 5 stimulated, TCR $\gamma \delta+$, long term T cell line from a patient with BD secreted IL4 and had a Th2 profile (unpublished data), suggesting that both pathogenic and protective immune responses may be induced by HSPs.

With the available data, an immunological model for the possible role of HSP65 as a T cell antigen is outlined in fig 1 . According to this model, human HSP60-reactive $\mathrm{T}$ cell clones, escaping high affinity clonal deletion, may be positively selected with low affinity in thymus where HSP60 is present as a self antigen and circulate in an anergic form (Th2 type?) in the peripheral blood. In oral mucosa and, possibly, in the skin, after non-specific minor injuries and oral ulcer development, streptococcal and human HSP60 expression may be up regulated, which stimulates self HSP60 reactive clones. These $\mathrm{T}$ cells might then pass to the ocular compartment (after non-specific anterior uveitis which breaks down the blood-retina barrier?), be further activated with retinalHSP60, and may cause a chronic ocular inflammation with Th1 type cytokine activity.

\section{$\alpha \beta$-CRYSTALLIN}

Other heat shock proteins may also be antigenic in BD. $\alpha \beta$-Crystallin is a small stress protein, constitutively present in vertebrate eye lens, skeletal muscle, and kidney epithelial cells. Stress-induced expression of $\alpha \beta$-crystallin in glia cells of the central nervous system has been demonstrated. ${ }^{54}$ Serum and CSF IgG and serum IgM antibody responses to $\alpha \beta$-crystallin are raised in patients with neuro-BD compared with patients with non-inflammatory nervous system diseases. ${ }^{55}$ When responses were subclassified according to the type of neuro-BD, similar to the anti-HSP65 responses, patients with parenchymal neuro-BD had higher CSF IgG responses to $\alpha \beta$-crystallin than the neuro-BD group with intracranial hypertension (vascular disease). CSF IgG responses to HSP 65 and $\alpha \beta$-crystallin also showed a significant correlation with each other, possibly owing to similar immune mechanisms driving both autoantibody responses in the CSF.

\section{Genetic predisposition and HLA-B51}

Behçet's disease has a strong genetic background with familial aggregation. ${ }^{56}$ Among various genetic markers, relationship to HLA class I antigens B5 and its subclass B51 is the most commonly reported, ${ }^{57}$ and linkage of the HLA-B locus in BD has also recently been shown. ${ }^{58}$ The presence of this marker has an odds ratio of 1.5 to 16 in different series. ${ }^{59} \mathrm{An}$

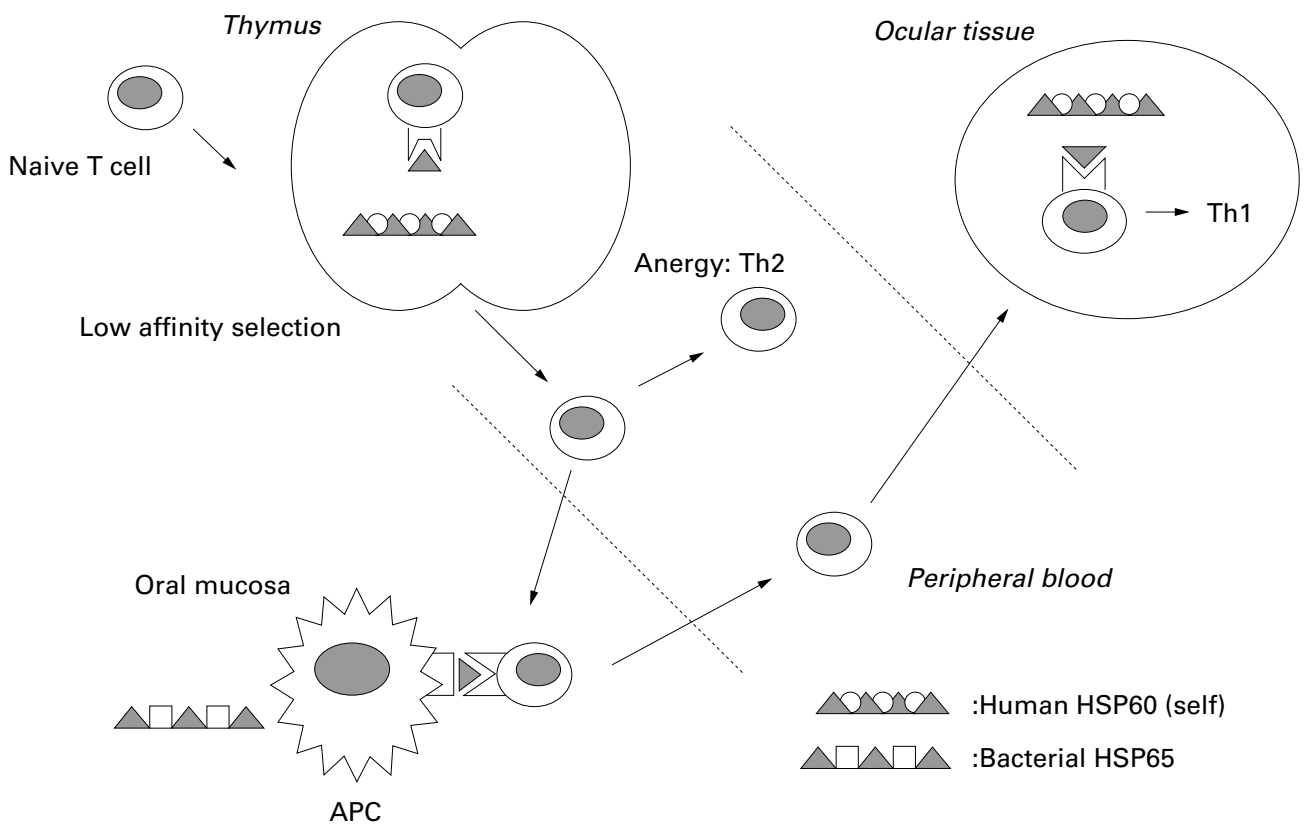

Figure 1 Role of bacterial and human heat shock protein (HSP) $60 / 65$ as T cell antigens in Behçet's disease. APC = antigen presenting cells. 
important question is whether B51 is a marker of susceptibility or severity in BD. Although a high prevalence is found in hospital based patients (50-80\%), ${ }^{60}$ a field study from Turkey found B5 in only $26 \%$ of the cases. ${ }^{61}$ Most patients in this study had not been diagnosed as BD previously and had a clinically mild, mucocutaneous disease.

The role of HLA class I antigens such as B51 is the presentation of endogenous antigens synthesised within the cell to CD8+ cytotoxicsuppressor $\mathrm{T}$ cells. The antigen-specific region of B51 has been analysed, and 8-10 amino acid length sequences of possible, antigenic peptides were reported..$^{62}$ Peptides derived from autoantigens, such as thymidylate synthase (aa 253-61), guanine-nucleotide binding protein $\beta$ subunit-like protein 12.3 (aa 192-200), or a yeast protein UBC5 (61-68), are among these candidate epitopes. HLA-B ${ }^{\star} 5101$ is the major subtype of HLA-B51 associated with BD and differs from HLA-B ${ }^{\star} 5201$, a split antigen of B5 but unlinked to BD, by only two amino acids at positions 63 and 67 which are in pocket $B$, the antigen-binding groove. These amino acids are possibly crucial anchor residues for peptide binding. Similarly, $B^{\star} 5101$ differs from $B \star 5102$ and $B \star 5103$ only at positions 171 and 167 , respectively. However, ${ }^{\star} 5102$ and ${ }^{\star} 5103$ are very rare alleles and whether they are not associated with $\mathrm{BD}$ only because of their low frequency is unknown. With this current knowledge, a candidate "Behçetogenic" epitope presented by ${ }^{\star} 5101$ is described as DAIXXXXXF, a hypothetical disease inducing peptide. ${ }^{62}$ The ${ }^{\star}$ B5108 and ${ }^{\star} 5109$ subtypes have also been detected in patients with BD recently, and their sequence analysis should also be explored and compared with that of $\star 5101 .{ }^{63}$

The role of HLA-B51-specific peptides and whether HLA-B51 restricted CD8+ $\mathrm{T}$ cells have a role in the cause of $\mathrm{BD}$ is currently unknown. ${ }^{64}$ As described above, HLA-B51 transgenic mice have an enhanced activation of neutrophils. ${ }^{6}$ Possibly, HLA-B51 may present an endogenous antigen to cytotoxic $\mathrm{T}$ cells in B51 transgenic mice and activate the cytokine cascade, causing superoxide release from neutrophils without a primary defect. ${ }^{64}$

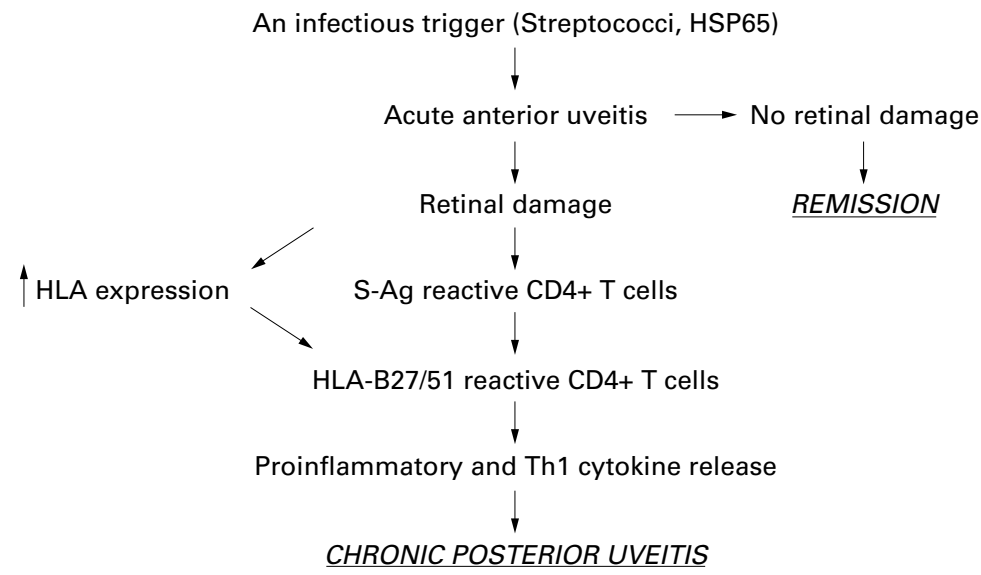

Figure 2 An immunological model for the role of cross reactive retinal-S antigen $(S-A g)$ and HLA-B27/51 derived peptides in chronic posterior uveitis of Behçet's disease.
Similarities between BD and Takayasu's arteritis also merit attention as this granulomatous, rare vasculitis, present in some countries such as Japan with a high prevalence of $\mathrm{BD}$, is strongly associated with HLA-B $\star 5201 .{ }^{65}$ Possible differences in binding peptides owing to two amino acid changes of HLA-B ${ }^{\star} 5201$ and *5101 seem to cause a very different clinical spectrum in the same geographical setting.

Another gene positioned close to B51 and found on the same haplotype may also be implicated in BD. Mizuki and Ohno first reported an association of MICA (MHC class I related gene) between the $\mathrm{TNF} \alpha$ gene and the HLA-B region on chromosome 6 , with $\mathrm{BD}{ }^{64}$ Although, associations of $\mathrm{BD}$ with triplet repeat microsatellite polymorphisms in the transmembrane region of the MICA gene, alleles A6 and A9, were also found in other studies, a strong linkage disequilibrium of MICA with HLA-B51 and its low heterogeneity make MICA an unlikely candidate as a major BD gene. ${ }^{66}$ However, MICA may still be a second gene relevant to $\mathrm{BD}$ as it has been shown to stimulate $\gamma \delta \mathrm{T}$ and NK cells. ${ }^{67}$ MICA is expressed mainly by endothelial cells and fibroblasts, but not by monocytes and keratinocytes, and endothelial expression of MICA may be a target antigen of antiendothelial responses such as graft rejection. ${ }^{68}$ Similarly, endothelial injury in BD may also be perpetuated by antiMICA responses.

\section{Retinal-S antigen and HLA-B51-new autoantigens?}

Another candidate autoantigen in $\mathrm{BD}$ is retinal-S antigen (S-Ag). This protein is found mainly in the retina and is possibly immuneprivileged, with immune responses only seen after tissue destruction owing to uveitis. T cell responses against $\mathrm{S}-\mathrm{Ag}$ are present in various types of human uveitis, including BD. ${ }^{69}$ Among the immunodominant epitopes of $\mathrm{S}-\mathrm{Ag}$, an epitope (aa 342-355, PDS-Ag) is found to share homology with a conserved region of HLA-B molecules (aa 125-138, B27PD) such as B51 and B27, which are linked to uveitis in BD and spondyloarthropathies. ${ }^{71}$ As this epitope is presented to and recognised by CD4+ T cells, a model in which class I HLA molecules become antigenic epitopes themselves is proposed. ${ }^{72}$ According to this model, HLA derived peptides are prominent in selecting the repertoire of CD4+ $\mathrm{T}$ cell reactivity and, as a consequence, in defining susceptibility to some autoimmune diseases. Indeed, a significant portion of small peptides eluded from the surface of various HLA class II molecules are found to originate from HLA class I, including B27PD. ${ }^{73}$ As $\mathrm{T}$ cells recognising class I antigens are a natural part of our immune repertoire, but possibly tolerised in thymus, a breakdown of tolerance may occur after uveal inflammation by cross reactivity of PDS-Ag and $\mathrm{B} 27 \mathrm{PD}$ reactive $\mathrm{T}$ cells (fig 2). Increased proinflammatory cytokine and chemokines in patients with uveitis may also enhance class I HLA molecule expression on cell surfaces, increasing their 
intracellular turnover and immune presentation. Development of uveitis in rats by both peptides is supportive of this model. ${ }^{71} \mathrm{~T}$ cell responses to these uveitogenic peptides were first shown in German patients with uveitis, ${ }^{71}$ and recently confirmed in a larger group of patients with BD from Turkey. ${ }^{74}$ Interestingly, only $\mathrm{T}$ cells from patients with posterior uveitis but not from the HLA-B51+ BD group without uveitis are responsive to uveitogenic peptides. This suggests that serious uvea destruction and activation of PDS-Ag reactive $\mathrm{T}$ cells is required for cross reactive anti$\mathrm{B} 27 \mathrm{PD}$ responses. Increased IL2 and $\mathrm{TNF} \alpha$ releases are also present after PDS-Ag and B27PD stimulation of peripheral blood mononuclear cells, with a proinflammatory, Th1 type of immune response. Oral feeding of B27PD derived peptide prevents S-Ag uveitis in the animal model ${ }^{71}$ and has now been tried in patients with refractory uveitis as a means of "oral tolerance" treatment. ${ }^{75}$

\section{Vascular disease and AECA}

Vascular involvement in BD is predominantly venous in contrast with systemic vasculitides. However, the rare presence of pulmonary emboli is suggestive of "sticky" thrombi, and in histopathological studies, in addition to thrombi, inflammatory infiltrates in vessel walls point to a vasculitic process. ${ }^{1}$ Vasculitis is also commonly present in the histopathological specimens of oral and genital ulcers, erythema nodosum-like lesions, epididymitis, enteritis, and central nervous system lesions of $\mathrm{BD}^{76}$ Non-lytic antibodies against endothelial cells are commonly present in both vascular and non-vascular BD. ${ }^{20}$ A $44 \mathrm{kDa}$ endothelial antigen is recognised by IgM AECAs of patients with BD. These antibodies increase the expression of ICAM-1 on endothelial cells and can activate the mitogen activated protein cascade through the extracellular signal regulated kinase. ${ }^{77}$ Increased factor $\mathrm{V}$ Leiden and the prothrombin gene G20210A mutations, mainly in patients with venous thrombosis and retinal occlusive disease, also show the role of increased propensity to thrombosis. ${ }^{78}$ Endothelium dependent, brachial artery flow mediated dilatation is also impaired in $\mathrm{BD}$, which is improved by vitamin $\mathrm{C}$ treatment and suggests a role for oxidative stress in vascular involvement. ${ }^{79}$

\section{Severity and sex}

One currently underexplored area is differences between the sexes in $\mathrm{BD}$, which is more severe in men. ${ }^{1}$ Severe complications, such as vascular, central nervous system, and pulmonary disease, as well as mortality, are related to the male sex.$^{80}$ However, serum levels of testosterone and oestradiol are not different in male patients with BD. ${ }^{81}$ Sebum excretion rates which are under androgenic control are increased in $\mathrm{BD}$, but also in patients with $\mathrm{RA} .^{82}$ Oestrogen is shown to protect against endotoxin induced uveitis in Lewis rats. In endotoxin induced uveitis, cellular infiltration is more marked in male than in female rats, and ovariectomy increases cellular infiltration. Oestrogen decreases E-selectin and IL6 gene expressions through oestrogen receptors in the vascular endothelium. ${ }^{83}$ As another mechanism, fMLP stimulated superoxide generation from neutrophils is decreased in vitro with oestrogen incubation. ${ }^{84}$ Through these mechanisms, oestrogen may suppress the proinflammatory functions of vascular endothelium and neutrophils, explaining the milder clinical course in women.

Behçet's syndrome: observations from the clinic. Different antigenic stimuli for different manifestations?

The name "Behçet's syndrome rather than Behçet's disease" is suggested by Ehrlich et al owing to a different, milder clinical course in Western populations than in patients with the classical course from the "silk route" ${ }^{85} \mathrm{Al}-$ though this approach has not been universally agreed, it might be helpful in elucidating the predisposing genetic and environmental factors. Various manifestations of BD occurring unpredictably during the disease course and not linked to any previous risk factor may be associated with different organ-specific antigens or genetic predispositions. Therapeutic trials provide interesting clues, as the effects of various popular treatments in $\mathrm{BD}$ seem to be organ-specific. Colchicine is especially effective for erythema nodosum-like lesions but has a limited effect on arthritis or uveitis. It is not uncommon to see mucocutaneous lesions relapse in patients receiving immunosuppressive treatment which prevents ocular attacks. In a recent trial, thalidomide was found to be effective for oral and genital ulcers, but caused a significant increase in erythema nodosum lesions in the first eight weeks. ${ }^{86}$ As an explanation for this surprising observation, the authors suggested that "the cause of aphthous ulcers and erythema nodosum may not have a common putative denominator in BD".

Immune responses to local antigens, such as dermal keratins in psoriasis or synovial antigens such as collagen type II in rheumatoid arthritis, have been reported. ${ }^{87}$ Similarly, local, organ-specific antigens may be immunopathogenic for patient subgroups with mucocutaneous, ocular, or articular organ involvement in BD. Retinal S-antigen derived PDS-Ag, with T cell recognition, found only in patients with posterior uveitis, is a candidate organ-specific antigen of this type. Similarly, the presence of anti-HSP60 antibodies, mainly in patients with parenchymal neuro-BD, but not in pure vascular form, underlines the fact that even within the same organ immune responses may reflect different clinical subtypes.

\section{Summary}

Both innate and adaptive immune systems are activated in $\mathrm{BD}$, with a proinflammatory and Th1-type of cytokine profile. BD may be linked to a specific, primary immune abnormality with a genetic mutation affecting an adhesion molecule or a proinflammatory cytokine, which predisposes to early or more intense neutrophil and $\mathrm{T}$ cell responses. Alternatively, a broad 
intracellular signalling abnormality of a transcription factor, which lowers the threshold of inflammatory responses to external stimuli, as proposed for familial Mediterranean fever with decreased pyrine expression of neutrophils, may be present (hyperreactivity model).

However, an adaptive immune system is also crucial in $\mathrm{BD}$, with possibly both external (streptococcal, superantigens) and internal (heat shock or organ-specific proteins) antigens driving the pathogenic tissue $\mathrm{T}$ cell infiltrations. Better characterisation of pathogenic immune cell subsets, systemic and local antigens, and abnormal cell-activation mechanisms may help in the future to develop more specific and less toxic immunotherapeutic approaches to the still unsatisfactorily treated BD.

The author thanks Professor H Yazici for critically reading the manuscript.

The studies by the author and his collaborators are supported with grants from Turkish Scientific and Technical Counci (TUBITAK)

1 Yazici H, Yurdakul S, Hamuryudan V. Behçet's syndrome. In: Klippel JH, Dieppe PA, eds. Rheumatology. London: Mosby, 1998;7:26:1-6.

2 Sakane T, Takeno M, Suzuki N, Inaba G. Behçet's disease. N Engl J Med 1999;341:1284-91.

3 Mege JL, Dilsen N, Sanguedolce V, Gul A, Bongrand P, Roux $\mathrm{H}$, et al. Overproduction of monocyte derived tumor necrosis factor alpha, interleukin-6, IL-8 and increased neutrophil superoxide generation in Behçet's disease. A neutrophil superoxide generation in Behçet's disease. A comparative study with familial Mediterranean

4 Pronai L, Ichikawa Y, Nakazawa H, Arimori S. Enhanced superoxide generation and the decreased superoxide scavenging activity of peripheral blood leucocytes in Behcet's disease - effects of colchicine. Clin Exp Rheumatol 1991;9:227-33.

5 Carletto A, Pacor ML, Biasi D, Caramaschi P, Zeminian S, Bellavite $\mathrm{P}$, et al. Changes of neutrophil migration without modification of in vitro metabolism and adhesion in Behçet's disease. J Rheumatol 1997;24:1332-6.

6 Takeno M, Kariyone A, Yamashita N, Takiguchi M, Mizushima Y, Kaneoka $\mathrm{H}$, et al. Excessive function of peripheral blood neutrophils from patients with Behcet's disease and from HLA-B51 transgenic mice. Arthritis Rheum 1995;38:426-33.

7 Tuzun B, Tuzun Y, Mat C, Yurdakul S, Hamuryudan V, Yazici $\mathrm{H}$, et al. Neutrophil chemotaxis in Behçet's syndrome. Ann Rheum Dis 1999;58:658.

8 Özgün S, Akoglu T, Direskeneli H, Sen LS, Lawrence R. Neutrophil adhesion to endothelial cells and factors affecting adhesion in patients with Behçet's disease. Ann Rheum ing adhesion in patie

9 Eksioglu-Demiralp E, Direskeneli H, Kibaroglu A, Yavuz S, Ergun T, Akoglu T. Neutrophil activation in Behçet's disease. Clin Exp Rheumatol (in press)

10 Hallett MB, Lloyds D. Neutrophil priming: the cellular signals that say "amber" but not "green". Immunology Today 1995; 16:264-8.

11 Direskeneli H, Eksioglu-Demiralp E, Kibaroglu A, Yavuz S, Ergun T, Akoglu T. Oligoclonal T cell expansions in patients with Behçet's disease. Clin Exp Immunol 1999; 117:166-70

12 Suzuki Y, Hoshi K, Matsuda T, Mizushima Y. Increased peripheral blood gamma delta $+\mathrm{T}$ cells and natural killer cells in Behcet's disease. J Rheumatol 1992;19:588-92.

13 Freysdottir J, Lau SH, Fortune F. Gamma delta+ T cells in Behçet's disease (BD) and recurrent aphthous stomatitis Behçet's disease (BD) and recurrent aphth
(RAS). Clin Exp Immunol 1999;118:451-7.

14 Sugi-Ikai N, Nakazawa M, Nakamura S, Ohno S, Minami $M$. Increased frequencies of interleukin-2 and interferongamma producing T cells in patients with active Behçet's disease. Invest Ophthalmol Vis Sci 1998;39:996-1004.

15 Frassanito MA, Dammacco R, Cafforio P, Dammacco F. Th1 polarization of the immune response in Behçet's disease: a putative pathogenic role of interleukin-12 Arthritis Rheum 1999;42:1967-74.

16 Mantas C, Direskeneli H, Eksioglu-Demiralp E, Akoglu T Serum levels of Th2 cytokines IL-4 and IL-10 in Behcet's disease. J Rheumatol 1999;26:510-12.

17 Raziuddin S, al-Dalaan A, Bahabri S, Siraj AK, al-Sedairy S. Divergent cytokine production profile in Behçet's disease. Altered Th1/Th2 cell cytokine pattern. J Rheumatol 1998; 25:329-33.

18 Yazici H. The place of Behçet's syndrome among the autoimmune diseases. Int Rev Immunol 1997;14:1-10.

19 Suzuki N, Sakane T, Ueda Y, Tsunematsu T. Abnormal B cell function in patients with Behçet's disease. Arthritis Rheum 1986;29:212-19.
20 Direskeneli H, Keser G, D'Cruz D, Khamashta MA, Akoglu $\mathrm{T}$, Yazici $\mathrm{H}$, et al. Anti-endothelial cell antibodies, endothelial proliferation and von Willebrand factor antigen in Behçet's disease. Clin Rheumatol 1995;14:55-61.

21 Matsui T, Kurokawa M, Kobata T, Oki S, Azuma M, Tohma $\mathrm{S}$, et al. Autoantibodies to $\mathrm{T}$ cell costimulatory molecules in systemic autoimmune diseases. J Immunol 1999;162: 4328-35.

22 Tokay S, Direskeneli H, Yurdakul S, Akoglu T. Anticardiolipin antibodies in Behçet's disease: a reassessment. Rheumatology (Oxford) 2001;40:192-5.

23 Eksioglu-Demiralp E, Kibaroglu A, Direskeneli H, Yavuz S, Karsli F, Yurdakul S, et al. Phenotypic characteristics of B cells in Behçet's disease: increased activity in B cell subsets. J Rheumatol 1999;26:826-32.

24 Behçet H. Uber rezidivierende, aphthose durch ein Virus verursachte Geschwure am Mund, am Auge und an den Genitalen. Dermatol Wochenschr 1937;105:1152-7.

25 Sezer F. The isolation of a virus as the cause of Behçet's disease. Am J Ophthalmol 1953;36:301-6.

26 Lehner T. The role of heat shock protein, microbial and auto-immune agents in the aetiology of Behcet's disease. Int Rev Immunol 1997;14:21-32.

27 Lee ES, Lee S, Bang D, Sohn S. Herpes simplex virus detection by polymerase chain reaction in intestinal ulcer of patients with Behçet's disease. In: M Hamza, ed. Proceedings of the $7^{\text {th }}$ International Conference on Behçet's Disease. Tunis, Tunisia: Pub Adhona, 1997; 71-4.

28 Sohn S, Lee ES, Bang D Lee S. Behçet's disease-like symptoms induced by the herpes simplex virus in ICR mice. Eur J Dermatol 1998;8:21-3.

29 Sohn S, Lee ES, Kwon HJ, Lee SI, Bang D, Lee S. Expression of Th2 cytokines decreases the development of and improves Behcet's disease-like symptoms induced by
herpes simplex virus in mice. J Infect Dis 2001;183: herpes $1180-6$.

30 The Behçet's Disease Research Committee of Japan. Skin hypersensitivity to streptococcal antigens and the induction of systemic symptoms by the antigens in Behçet's disease a multicenter study. J Rheumatol 1989;16:506-11.

31 Calguneri M, Kiraz S, Ertenli I, Benekli M, Karaarslan Y, Celik I. The effect of prophylactic penicillin treatment on the course of arthritis episodes in patients with Behçet's disease. A randomized clinical trial. Arthritis Rheum 1996; 39:2062-5.

32 Hirohata S, Oka H, Mizushima Y. Streptococcal-related antigens stimulate production of IL-6 and interferonantigens stimulate production of IL-6 and interferonImmunol 1992;140:410-19.

33 Mochizuki N, Suzuki N, Takeno M, Nagafuchi H, Harada $\mathrm{T}$, Kaneoka $\mathrm{H}$, et al. Fine antigen specificity of human gamma delta $\mathrm{T}$ cell lines (V gamma $9+$ ) established by repetitive stimulation with a serotype (KTH-1) of a grampositive bacterium, Streptococcus sanguis. Eur J Immunol 1994;24:1536-43.

34 Hirohata S, Hashimoto T. Abnormal T cell responses to bacterial superantigens in Behçet's disease (BD). Clin Exp Immunol 1998;112:17-24.

35 Lamb JR, Young DB. T cell recognition of stress proteins. A link between infectious and autoimmune diseases. Mol Biol Med 1990;7:311-21.

36 Ergun T, Ince Ü, Eksioglu-Demiralp E, Direskeneli H, Gürbüz O, Gürses L, et al. Expression of $60 \mathrm{kD}$ heat shock protein in mucocutaneous lesions in Behçet's disease. J Am Acad Dermatol (in press).

37 Lehner T, Lavery E, Smith R, van der Zee R, Mizushima Y, Shinnick T. Association between the 65-kilodalton heat shock protein, Streptococcus sanguis, and the corresponding antibodies in Behçet's syndrome. Infect Immun 1991;59:1434-41.

38 Pervin K, Childerstone A, Shinnick T, Mizushima Y, van der Zee R, Hasan A, et al. T cell epitope expression of mycobacterial and homologous human 65-kilodalton heat shock protein peptides in short term cell lines from patients with Behcet's disease. J Immunol 1993;151:2273-82.

39 Direskeneli H, Hasan A, Shinnick T, Mizushima Y, van der Zee R, Fortune F, et al. Recognition of B cell epitopes of the $65 \mathrm{kDa}$ HSP in Behçet's disease. Scand J Immunol 1996:43:464-471

40 Hasan A, Fortune F, Wilson A, Warr K, Shinnick T, Mizushima Y, et al. Role of gamma delta T cells in pathogenesis and diagnosis of Behçet's disease. Lancet 1996; 347:789-94.

41 Kaneko S, Suzuki N, Yamashita N, Nagafuchi H, Nakajima $\mathrm{T}$, Wakisaka $\mathrm{S}$, et al. Characterization of T cells specific for an epitope of human $60 \mathrm{kD}$ heat shock protein (hsp) in patients with Behcet's disease in Japan. Clin Exp Immunol 1997;108:204-11.

42 Direskeneli H, Eksioglu-Demiralp E, Yavuz S, Ergun T, Shinnick T, Lehner T, et al. T cell responses to $60 / 65 \mathrm{kD}$ heat shock protein derived peptides in Turkish patients with Behçet's disease. J Rheumatol 2000;27:708-13.

43 Kibaroglu A, Eksioglu-Demiralp E, Direskeneli H, Akoglu T. Changes in lymphocyte subsets with microbial and auto-immune antigens in Behcet's disease [abstract]. Arthritis Rheum 1999;42 \{suppl):9:5319.

44 Saruhan-Direskeneli G, Celet B, Direskeneli H. The response of the HSP65 specific T cell lines to human HSP60 peptides in Behçet's disease [abstract]. $8^{\text {th }}$ International Congress on Behçet's Disease. 7-9 October 1998, Reggio-Emilia Italy. Alphagine-Cremona: Prex s.r.1., P49 (148). 
45 Eksioglu-Demiralp-E, Direskeneli H, Ergun T, Fresko I, Akoglu T. Increased CD4+CD16+ and CD4+CD56+ T Akoglu T. Increased CD4+CD16+ and CD4+CD56+ T 23-6.

46 Tanaka T, Yamakawa N, Koike N, Suzuki J, Mizuno F, Usui $M$. Behçet's disease and antibody titers to various heat-shock protein $60 \mathrm{~s}$. Ocular Immunology and Inflammation 1999;7:69-74.

47 Tasçi B, Direskeneli H, Serdaroglu P, Akman-Demir G, Eraksoy M, Saruhan-Direskeneli G. Humoral immune response to myco-bacterial heat shock protein (hsp) 65 in the cerebrospinal fluid of neuro-Behçet patients. Clin Exp Immunol 1998;113:100-4

48 Stanford MR, Kasp E, Whiston R, Hasan A, Todryk S, Shinnick $\mathrm{T}$, et al. Heat shock protein peptides reactive in patients with Behçet's disease are uveitogenic in Lewis rats. Clin Exp Immunol 1994; 97:226-31.

$49 \mathrm{Hu}$ W, Hasan A, Wilson A, Stanford MR, Li-Yang Y, Todryk $\mathrm{S}$, et al. Experimental mucosal induction of uveitis with the $60 \mathrm{kDa}$ heat shock protein-derived peptide $336-51$. Eur J Immunol 1998;28:2444-55.

50 Isogai E, Isogai H, Kimura K, Fujii N, Kotake S, Yoshikawa $\mathrm{K}$, et al. Infection of gnotobiotic mice with Streptococcus sanguis associated with Behçet's disease [abstract]. $9^{\text {th }}$ International Conference on Behçet's Disease. Yonsei Med J 2000;41:(suppl): L13, P12.

51 Van Eden W, van der Zee R, Paul AGA, Prakken BJ, Wendling U, Anderton SM, et al. Do heat shock proteins control the balance of T-cell regulation in inflammatory diseases? Immunol Today 1998;19:303-7.

52 De Graeff-Meeder ER, van Eden W, Rijkers GT, Prakken BJ, Kuis W, Voorhorst-Ogink MM, et al. Juvenile chronic arthritis: T cell reactivity to human HSP60 in patients with a favorable course of arthritis. J Clin Invest 1995;95:934 40.

53 Takeno M, Nagafuchi $H$, Takeba Y, Suzuki N, Sakane T. The pathogenic role of autoreactive $T$ cells specific for the human heat shock protein $60 \mathrm{kD}$-derived peptides in Behcet's disease [abstract]. Arthritis Rheum 2000;43 (suppl 9):S124 (345).

54 Bairamovic JJ, Lassmann H, van Noort JM. Expression of alphaB-crystallin in glia cells during lesional developmen in multiple sclerosis. J Neuroimmunol 1997;78:143-51.

55 Celet B, Akman-Demir G, Serdaroglu P, Yentür S, Tasci B, van Noort J, et al. Anti- $\alpha \beta$-crystallin immunoreactivity in inflammatory nervous system diseases. J Neurol 2000;247: 935-9.

56 Gul A, Inanç M, Ocal L, Aral O, Koniçe M. Familial aggregation of Behçet's disease in Turkey. Ann Rheum Dis 2000;59:622-5

57 Ohno S, Ohguchi M, Hirose S, Matsuda H, Wakisaka A Aizawa $\mathrm{H}$. Close association of HLA-Bw51 with Behçet's disease. Arch Ophthalmol 1982;100:1455-8.

58 Gul A, Hajeer AH, Worthington J, Barrett JH, Ollier WE, Silman AJ. Evidence for linkage of the HLA-B locus in Behcet's disease obtained using transmission disequilibrium test. Arthritis Rheum 2001;44:239-40.

59 Verity DH, Marr JE, Ohno S, Wallace GR, Stanford MR. Behçet's disease, the silk road and HLA-B51: historical and Behçet's disease, the silk road and HLA-B51: historical and geogras.

60 Yazici H, Akokan G, Yalçin B, Muftuoglu A. The high prevalence of HLA-B5 in Behçet's disease. Clin Exp Immunol 1977;30:259-61.

61 Yurdakul S, Gunaydin I, Tuzun Y, Tankurt N, Pazarli H, Ozyazgan Y, et al. The prevalence of Behçet's syndrome in a rural area in northern Turkey. J Rheumatol 1988;15: $820-2$

62 Falk K, Rotzschke O, Takiguchi M, Gnau V, Stevanovic S, Jung G, et al. Peptide motifs of HLA-B51, -B52, and -B78 molecules and implications for Behçet's disease. Int Immunol 1995; $7: 223-8$.

63 Mizuki N, Inoko H, Ohno S. Pathogenic gene responsible for the predisposition of Behçet's disease. Int Rev Immunol 1997;14:33-48.

64 Mizuki N, Ohno S. Immunogenetic studies of Behçet's disease. Rev Rhum Engl Ed 1996;63:520-7.

65 Kimura A, Kitamura H, Date Y, Numano F. Comprehensive analysis of HLA genes in Takayasu arteritis in Japan. Int J Cardiol 1996:54 \{suppl):S61-9.
66 Mizuki N, Ota M, Katsuyama Y, Yabuki K, Ando H, Goto $\mathrm{K}$, et al. Association analysis between the MIC-A and HLA-B alleles in Japanese patient

67 Bauer S, Groh V, Wu J, Steinle A, Phillips JH, Lanier LL, et al. Activation of NK cells and T cells by NKG2D, a receptor for stress-inducible MICA. Science 1999;285:727-9.

68 Zwirner NW, Dole K, Stastny P. Differential surface expression of MICA by endothelial cells, fibroblasts, keratinocytes and monocytes. Hum Immunol 1999;60:323-30.

69 De Smet MD, Yamamoto JH, Mochizuki M, Gery I, Singh VK, Shinohara $\mathrm{T}$, et al. Cellular immune responses of patients with uveitis to retinal antigens and their fragments. Am J Ophthalmol 1990;110:135-42.

70 Yamamoto JH, Minami M, Inaba G, Masuda K, Mochizuki M. Cellular autoimmunity to retinal specific antigens in patients with Behçet's disease. Br J Ophthalmol 1993;77. 584-9.

71 Wildner G, Thurau SR. Cross-reactivity between an HLAB27-derived peptide and a retinal autoantigen peptide: a clue to major histocompatibility complex association with auto-immune disease. Eur J Immunol 1994;24:2579-85.

72 Baum H, Davies H, Peakman M. Molecular mimicry in the MHC: hidden clues to autoimmunity? Immunol Today 1996; 17:64-70.

73 Chicz RM, Urban RG, Gorga JC, Vignali DA, Lane WS, Strominger JL. Specificity and promiscuity among natually processed peptides bound to HLA-DR alleles. J Exp Med 1993;178:27-47.

74 Kurhan-Yavuz S, Direskeneli H, Bozkurt N, Ozyazgan Y, Bavbek T, Kazokoglu $\mathrm{H}$, et al. Anti-MHC autoimmunity in Behçet's disease: T cell responses to an HLA-B derived peptide cross-reactive with retinal-S antigen in

75 Thurau SR, Diedrichs-Mohring M, Fricke H, Burchardi C, Wildner G. Oral tolerance with an HLA-peptide mimicking retinal autoantigen as a treatment of autoimmune uveitis. Immunol Lett 1999;68:205-12.

76 Ehrlich GE. Vasculitis in Behçet's disease. Int Rev Immunol 1997;14:81-8.

77 Cho HJ, Bang D, Lee S, Lee WJ, Lee KH. Signal transduction pathway in activation of endothelial cell antibodies in era of patients with Behçet's disease [abstract]. $9^{\text {th }}$ International Conference on Behçet's Disease. Yonsei Med J 2000;41 (suppl):L26, P15.

78 Gul A, Aslantas AB, Tekinay T, Koniçe M, Ozcelik T. Procoagulant mutations and venous thrombosis in Behçet's disease. Rheumatology (Oxford) 1999;38:1298-9.

79 Chambers JC, Haskard DO, Kooner JS. Vascular endothelial function and oxidative stress mechanisms in patients with Behçet's syndrome. J Am Coll Cardiol 2001;37:51720.

80 Yazici H, Basaran G, Hamuryudan V, Hizli N, Yurdakul S, Mat C, et al. The ten-year mortality in Behçet's syndrome. Br J Rheumatol 1996;35:139-41.

81 Yazici H, Hekim N, Tüzün N, Serdaroglu S, Kotagyan A, $\mathrm{Oz} \mathrm{F}$, et al. Sex factor and Behçet's syndrome. In: Lehner T, Barnes CG, eds. Recent advances in Behcet's disease. Barnes CG, eds. Recent advances in Behçet's

82 Yazici H, Mat C, Deniz S, Iscimen A, Yudakul S, Tuzun Y, t al. Sebum production is increased in Behcet's syndrome and even more so in rheumatoid arthritis. Clin Exp Rheumatol 1987;5:371-4.

83 Miyamoto N, Mandai M, Suzuma I, Suzuma K, Kobayashi $\mathrm{K}$, Honda Y. Estrogen protects against cellular infiltration by reducing the expressions of E-selectin and IL-6 in endotoxin-induced uveitis. J Immunol 1999;163:374-9.

84 Buyon JP, Korchak HM, Rutherford LE, Ganguly M, Weissmann G. Female hormones reduce neutrophil responsiveness in vitro. Arthritis Rheum 1984;27:623-30.

85 Ehrlich GE. Behçet's disease and the emergence of thalidomide. Ann Intern Med 1998;128:494-5.

86 Hamuryudan V, Mat C, Saip S, Ozyazgan Y, Siva A, Yurdakul S, et al. Thalidomide in the treatment of the muco-cutaneous lesions of the Behcet's syndrome. A randomized, double-blind, placebo-controlled trial. Ann Intern Med 1998;128:443-50.

87 Blass S, Engel JM, Burmester GR. The immunological homunculus in rheumatoid arthritis. Arthritis Rheum 1999;42:2499-506. 